\title{
Ozone Effects on Plants: Two Opposite Sides of the Same Coin
}

\author{
José Efraín González Ramírez* \\ Plant Protection Directorate, Tropical Viandas Research Institute (INIVIT), Cuba \\ *Corresponding author: José Efraín González Ramírez, Plant Protection Directorate, Tropical Viandas Research Institute \\ (INIVIT), 53 000, Santo Domingo, Villa Clara, Cuba
}

\begin{tabular}{lll}
\hline ARTICLE INFO & & ABSTRACT \\
$\begin{array}{l}\text { Received: 幽 July 03, } 2019 \\
\text { Published: }\end{array}$ & & $\begin{array}{l}\text { Citation: José Efraín González Ramírez. Ozone Effects on Plants: Two Opposite Sides of } \\
\text { the Same Coin. Biomed J Sci \& Tech Res 19(3)-2019. BJSTR. MS.ID.003297. }\end{array}$ \\
\hline
\end{tabular}

\section{Introduction}

Ozone, or trioxygen, is an inorganic molecule with the chemical formula $\mathrm{O}_{3}$ [1]. It is formed from dioxygen by the action of ultraviolet light (UV) and electrical discharges within the Earth's atmosphere and touches on our modern society in many ways. Ozone is used in industrial processes and as a disinfectant due it is a strong oxidizing agent. It is a "good" gas when present in the stratosphere, where it forms the ozone layer sitting 15 to 30 kilometers above Earth that protect life from detrimental ultraviolet radiation, but when present in the lowest atmospheric layer (the troposphere, which extends 8 to 14 kilometers above Earth) ozone becomes a concern for human and plant health [2]. Our basic understanding of ozone began with the recognition by Christian Friedrich Schönbein in 1840 that ozone was a unique substance produced in a variety of processes. It cannot be stored and must be generated continuously. The only result of ozone, when it decomposes, is oxygen; so, no chemical residues are related with ozone.

\section{Air Pollutant and Agricultural Damages}

Ozone is a secondary air pollutant at troposphere. This means that ozone is not formed directly in the ambient air by human activities, but by photochemistry, as a result of the irradiation of primary pollutants (such as $\mathrm{NO}^{2}$ ) by ultra-violet radiation (UV) in the presence of oxygen [3]. Chronic plants exposure to ozone causes damaging changes in plant metabolism. Cell's damages due ozone are first displayed at the biochemical level before visible morphological symptoms can be seen [4]. Photosynthesis, respiration, nitrogen and lipid exchanges are all affected, along with the activities of the secondary metabolism. Later, visible damage appears, such as necrotic spots and bronze coloration on leaves
$[3,4]$. Ground-level ozone is a threat to food production as it has a negative impact on the yield and quality of important staple crops [5]. Some important agricultural regions located close to urban and industrial centres experience elevated ozone concentrations; these include the Midwestern USA, much of mainland Europe, the South Asia's Indo-Gangetic plains, and the coast of China.

Global relative yield losses due to $\mathrm{O}_{3}$ damage are estimated to range between $7 \%$ and $12 \%$ for wheat, $6 \%$ and $16 \%$ for soybean, $3 \%$ and $4 \%$ for rice and $3 \%$ and $5 \%$ for maize $[4,6]$. In India it was calculated that $\mathrm{O}_{3}$ damage to wheat and rice resulted in a nationally aggregated yield loss of $9.2 \%$, that is sufficient to feed 94 million people living below the poverty line in that country [7]. In developing countries, especially South and East Asia, ozone levels are rising and this trend will continue at least until 2030 unless emissions of ozone precursors are reduced significantly. Many countries have begun to establishing policies to control ozone's levels by regulating its precursors, imposing regionally specific emission fees which are leading to reduce agricultural damages [6,8-10] and, also development robust crop growth models capable of including ozone effects that would substantially improve future national, regional and global risk assessments that aim to assess the role that ozone might play under future climatic conditions in limiting food supply.

\section{Ozone and Reactive Oxygen Species}

Not all ozone interaction with plant leads to tissue damages. plants are able to assimilate certain amounts of ozone which can be used to their benefit. The 'effective ozone flux' concept is based on a balance between stomatal flux and leaf cellular detoxification 
[11]. The degree of stomatal opening controls the quantity of ozone molecules entering the leaf and subsequently being converted to Reactive Oxigen Species (ROS) including superoxide $\left(\mathrm{O}_{2}\right.$ ), hydrogen peroxide $\left(\mathrm{H}_{2} \mathrm{O}_{2}\right)$, hydroxyl radical $\left(\mathrm{OH}_{3}\right)$, and all are involucre in several metabolism pathways [12]. Therefore, plant tissue could metabolize low doses of ozone without suffer any damages. As in many other cases, the doses could be master key to achieve damages or beneficial effects from ozone.

\section{Ozone as Superficial Disinfection Agent}

Ozone and ROS show high oxidation potential, for example, hydroxyl radical which have oxidation potential of $2,83 \mathrm{v}$, even higher of the one from $\mathrm{O}_{3}(2,08 \mathrm{v})$ very close of fluor one $(2,87 \mathrm{v})$ the higher of any natural elements on earth [13]. this property together with its low residuality make it an environmentally friendly alternative for the elimination of unwanted microorganisms in certain crop stages $[1,14]$. Microbial disinfection during initiation to in vitro tissue culture has been achieved in Lillium sp. and Dioscorea sp. $[15,16]$. similar results have been possible during the post-harvest benefit of fruits and vegetables $[17,18]$ replacing toxic compounds like chemical fungicides or sodium hypochlorite typically used in both cases. Also, economic efficiency results higher due the implementation of ozone treatment, both in atmosphere or water dissolved ozone, in all related cases.

\section{ROS and Plant Cell Metabolism}

(ROS) play a dual role in plant biology. They are required for many important signaling reactions, including the growth, development and responses to the environments but are also toxic byproducts of aerobic metabolism [12,19,20]. Previous studies document the favorable effect of $\mathrm{H}_{2} \mathrm{O}_{2}$ on the germination and quality of the seeds. Hameed and colleagues reported the positive effect of hydrogen peroxide on the root and growth of wheat seedlings [21], other group in Japan obtained greater germination of rice seeds and seedling growth [22], while Orabi and colleagues described similar effects in canola seeds [23]. Later it has been known that ozone treatment may elicit ROS signaling for some plant hormones pathways such as the salicylic acid (SA) or jasmonic acid (JA) [24-26] that are crucial in systemic acquired resistance (SAR), a plant defense against biotic or abiotic stress [26-28]. It has been revealed that ROS are necessary for several basic biological processes including cellular proliferation and differentiation.

Moreover, cell death that was previously thought to be the outcome of ROS directly killing cells by oxidation is now considered to be the result of ROS triggering a physiological or programmed pathway for cell death and thus maintaining a basal level of ROS in cells is essential for life [12]. It is necessary more studies to know all the details related with metabolic ROS pathways. Anyway, there are increases of ozone use in order to protect plant. Again, the correct dosses result crucial to obtain a beneficial instead damage effect. In this sense, ozone applied in vegetable seeds achieved efficiencies between 29 and $59 \%$ in the sanitation of viruses [29] and treatments with ozone dissolved in water achieve the maintenance of $62 \%$ of potyvirus-free yam seedlings [30] and reduce the time required for micropropagation process due to the stimulation of growth in obtained seedlings. In each case, special attention must be paid to the design of efficient and safe ways and methods for the application of ozone in order to achieve the expected results $[1,13,30]$.

\section{Conclusion}

Further researches are needed in both sides of ozone-plant interaction. First, researchers are challenged to improve our ability to quantify and forecast effects of ozone on crop yield and quality and to develop resilient agricultural systems would ideally integrate adaptation to avoid the worst effects from ozone pollution alongside climate change through improved crop breeding and agronomic practices. Secondly, it would be important to achieve a better understanding of metabolic events signaled by ROS, during biotic or abiotic stress in plants. Moreover, it will be interesting to address the mechanisms that determine the ROS signal specificity in Pathogens-associated molecular patterns (PAMP) triggered immunity (PTI), effector-triggered immunity (ETI), principal plant defense strategies against pathogens in nature. This knowledge will lead to better uses of ozone in plant protection.

\section{References}

1. Prabha V, Barma RD, Singh R, A Madan (2015) Ozone Technology in Food Processing: A Review. Trends in Biosciences 8: 4031-4047.

2. Jasaitis D, Vasiliauskiene V, Chadyšiene R, M Peciuliene (2016) Surface Ozone Concentration and Its Relationship with UV Radiation, Meteorological Parameters and Radon on the Eastern Coast of the Baltic Sea. Atmosphere 7(2): 27.

3. Roshchina VV, VD Roshchina (2003) Ozone-Induced Changes in Plant Metabolism. In: Ozone and Plant Cell 127-152.

4. Emberson LD, Pleijelb H, Ainsworthc EA, van den Berg M, Rene W, et al. (2018) Ozone effects on crops and consideration in crop models. European Journal of Agronomy 100:19-34.

5. Ainsworth EA, Yendrek CR, Sitch S, Collins WJ, LD Emberson, et al. (2012) The effects of tropospheric ozone on net primary productivity and implications for climate change. Annual Review of Plant Biololy 63: 637-663.

6. Van Dingenen R, Dentener FJ, Raes F, Krol MC, Emberson L, et al. (2009) The global impact of ozone on agricultural crop yields under current and future air quality legislation. Atmosphere Environmental, 43(3): 604-618.

7. Ghude SD, Jena C, Chate DM, Beig G, Pfister GG, et al. (2014) Reductions in India's crop yield due to ozone. Geophyical Research Letter 41(15): 5685-5691.

8. Fujin Y, McCarl BA, Zhou X, F Jiang (2017) Damages of surface ozone: evidence from agricultural sector in China. Environmental Research Letters 13.

9. U.S. EPA (2006) Air Quality Criteria for Ozone and Related Photochemical Oxidants EPA/600/R-05/004aF-cF. U.S. Environmental Protection Agency, Washington, D.C.

10. UNECE, (1998) Convention on Long-Range Transboundary Air Pollution, UNECE, Geneva.

11. Dizengremel P, Le Thiec D, Hasenfratz Sauder MP, Vaultier MN, Bagard $\mathrm{M}$, et al. (2009) Metabolic-dependent changes in plant cell redox power after ozone exposure. Plant Biology 11: 35-42. 
12. Mittler R (2017) ROS Are Good. Trends in Plant Science 22(1).

13. Hoigné J, H Bader (1977) The Role of Hydroxyl Radical Reactions in Ozonation Processes in Aqueous Solutions. Water Research 10(5): 37786.

14. Msayleb N, R Kanwar, H Wu, J van Leeuwen (2017) Soil Ozonation for Nematode Disinfestation as an Alternative to Methyl Bromide and Nematicides. Scientific Pages of Environmental Studies 1(1): 11-19.

15. Cabrera M, JE González (2014) Ozone as an Alternative for Disinfection of Explants during in Vitro Mass Plant Propagation. Ozone: Science \& Engineering. 36(5): 435-439.

16. Cardarelli M, CM Cardona (2017) Influence of ozone treatments on in vitro propagation of Liliumin bioreactor. Actas de Horticultura 1155: 381-385.

17. Bataller M, González JE, Véliz E, LA Fernández (2012) Ozone Applications in the Post-Harvest of Papaya (Carica PapayaL.): An Alternative of Amistar Fungicide. Ozone: Science \& Engineering 34(3): 151-55.

18. Aguayo E, Escalona V, Silveira AC,F Artés (2013) Quality of tomato slices disinfected with ozonated water. Food Science and Technology International 20(3): 227-235.

19. Sandermann H, Ernst D, Heller W, Langebartels C (1998) Ozone: An abiotic elicitor of plant defence reactions. Trends in Plant Science 3(2): 47-50.

20. Inupakutika MA, Sengupta S, Devireddy AR, Azad RK, R Mittler, et a (2016) The evolution of reactive oxygen species metabolism. Journal of Experimental Botany 67 (21) 5933-5943.

21. Hameed A, Farooq S, Iqbal N, R Arshad (2004) Influence of Exogenous Application of Hydrogen Peroxide on Root and Seedling Growth on Wheat (Triticum aestivum L.). International Journal of Agriculture \& Biology. 6(2):366-369.

\section{ISSN: 2574-1241}

DOI: 10.26717/BJSTR.2019.19.003297

José Efraín González Ramírez. Biomed J Sci \& Tech Res

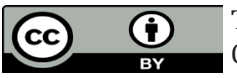

This work is licensed under Creative

Commons Attribution 4.0 License

Submission Link: https://biomedres.us/submit-manuscript.php
22. Sasaki K, Kishitani S, Abe F, T Sato (2005) Promotion of Seedling Growth of Seeds of Rice (Oryza sativa L. cv. Hitomebore) by Treatment with $\mathrm{H}_{2} \mathrm{O}_{2}$ before Sowing. Plant Production Science 8(5): 509-514.

23. Orabi SA, Hussein MM, Sazaki S, FA Sharara (2018) Influence of hydrogen peroxide on growth, yield and biochemical constituents of canola plants grown under different irrigation intervals. Current Science International 07(3): 407-418.

24. Pazarlar S, Cetinkaya N, Bor M , F Ozdemir (2017) Ozone triggers different defence mechanisms against powdery mildew (Blumeria graminis DC. Speer f. sp. tritici) in susceptible and resistant wheat genotypes. Functional Plant Biology 44(10): 1016-1028.

25. Onaga G, K Wydra (2017) Advances in Plant Tolerance to Biotic Stresses. Plant Genomics.

26. Jwa NS, Hwang BK (2017) Convergent Evolution of Pathogen Effectors toward Reactive Oxygen Species Signaling Networks in Plants. Front. Plant Sci 8.

27. Muhammad A, Cheng Z, Ahmad H, S Hayat (2018) Reactive oxygen species (ROS) as defenses against a broad range of plant fungal infections and case study on ROS employed by crops against Verticillium dahliae wilts. Journal of Plant Interactions 13(1): 353-363.

28. Aakanksha W, Pradeep K Pathak, K Jagadis Gupta (2018) Trichoderma asperelloides enhances local (LAR) and systemic acquired resistance (SAR) response under low nitrate nutrition in Arabidopsis.

29. Paylan IC, Erkan S, Cetinkaya N, Ergun M, S Pazarlar, et al. (2014) Effects of Different Treatments on the Inactivation of Various Seedborne Viruses in Some Vegetables. Ozone: Science \& Engineering 36(5): 422-26.

30. González JE, Cabrera M, Robaina A, Rodríguez D, González A, et al. (2019) Water-Dissolved Ozone Mediates Potyvirus Sanitation during In Vitro Propagation of Dioscorea Cayenensis Subsp. Rotundata (Poir.) Miège. Ozone: Science \& Engineering.

$\begin{array}{ll}\text { BIOMEDICAL } & \text { Assets of Publishing with us } \\ \text { RESEARCHES } & \text { Global archiving of articles } \\ & \text { - Immediate, unrestricted online access } \\ & \text { - Rigorous Peer Review Process } \\ \end{array}$

